\title{
Asthma, Food Allergy, and How They Relate to Each Other
}

\author{
Ru-Xin Foong ${ }^{1,2}$, George du Toit ${ }^{1}$ and Adam T. Fox ${ }^{1 *}$ \\ 'Division of Asthma, Allergy and Lung Biology, Department of Paediatric Allergy, King's College London, Guy's and St. \\ Thomas' Hospitals NHS Foundation Trust, London, UK, ${ }^{2}$ Institute of Child Health, University College of London, London, UK
}

The association between atopic diseases is well known, and previous research has shown that having one atopic disease can predispose to having another. The link between asthma and food allergy has been well researched, but the exact relationship between the two atopic conditions is not fully understood. Food allergic infants are at increased risk for the development of asthma and are at risk of food-induced asthmatic episodes and also anaphylaxis. Having a diagnosis of both food allergy and asthma has also been shown to have an effect on the severity of a patient's disease including being at greater risk of severe asthmatic episodes. Therefore, understanding the relationship between these two conditions in order to treat and manage these children safely is crucial to clinicians.

Keywords: asthma, food allergy, children, wheeze, anaphylaxis

\section{OPEN ACCESS}

Edited by:

Carlo Caffarelli,

University of Parma, Italy

Reviewed by:

Elisabetta Calamelli,

University of Bologna, Italy

Yusei Ohshima,

University of Fukui, Japan

*Correspondence:

Adam T. Fox

adam.fox@gstt.nhs.uk

Specialty section: This article was submitted to Pediatric Pulmonology, a section of the journal

Frontiers in Pediatrics

Received: 19 January 2017 Accepted: 10 April 2017 Published: 09 May 2017

Citation: Foong RX, du Toit G and Fox AT (2017) Asthma, Food Allergy, and How They Relate to Each Other.

Front. Pediatr. 5:89.

doi: 10.3389/fped.2017.00089

\section{BACKGROUND}

Diseases including asthma, eczema, allergic rhinitis, and food allergy are typically considered as allergic diseases, although the exact association with atopy is frequently debated for eczema and asthma. Nonetheless, such diseases commonly coexist and are common in pediatric populations worldwide. Children affected with one allergic disease frequently develop other allergic diseases. The sequence of disease progression is often referred to as the "atopic march" (1). For example, infants with eczema are at higher risk of developing food allergy, children with egg allergy are at increased risk of developing allergic respiratory diseases, and children with allergic rhinoconjunctivitis are at increased risk of developing asthma. Furthermore, children with a single food allergy frequently develop additional food allergies. The causal relationship between these atopic diseases remains unclear as it is not absolute in all patients and the sequence may vary (2-5). The dual-allergen hypothesis provides a plausible explanation as to how allergic disease may progress. It describes how early allergic sensitization occurs through breakdown of skin barrier integrity that allows for exposure to food and environmental allergen, an effect that can be moderated be early-life ingestion for foods such as peanut and is some studies hens egg (6-10). Research has shown that the development of eczema can be associated with mutations of the filaggrin gene that is responsible for a major structural protein in the epidermis (11). Thus, children with eczema are at greater risk of developing food allergies due to a weakened skin barrier; for example, a study reported that $50 \%$ of children with eczema developed food allergy by 1 year (12). Similarly, Martin et al. (13) showed that in infants with eczema, the earlier onset and greater severity of their eczema symptoms increased their risk of food allergy. This emphasizes the hypothesis that allergen exposure through the cutaneous route contributes to allergic sensitization and highlights the key role of skin barrier integrity in protecting the infant immune system, which has been seen in children sensitized to peanut allergy $(14,15)$. A review showed that approximately $70 \%$ of patients with severe eczema developed asthma or allergic rhinitis later in life, and asthmatic patients who had filaggrin mutations had a difficult disease course with more asthma exacerbations (11). Other work has shown that patients who have filaggrin 
loss-of-function mutations have a significant association with food challenge confirmed peanut allergy (16).

\section{Asthma}

Asthma is one of the most common long-term childhood conditions of which approximately $9 \%$ of children are affected by it (17). Asthma is defined as a chronic respiratory disease characterized by recurrent attacks of wheeze and breathlessness. These symptoms occur due to irritation that occurs in the airways causing inflammation and swelling resulting in reduced lung airflow (18). Over time with advances in asthma medicine, management continues to change but treatment primarily focuses on assessment of asthma severity, the use of acute and chronic medications including bronchodilators, anti-inflammatory medication (i.e., steroids), and treatment of comorbidities (19). In the management of acute asthma, the goals are to reverse airflow obstruction, correct significant hypoxia, and prevent future relapses (20). In order to achieve this, management for acute exacerbations includes the use of oxygen, short-acting inhaled beta-agonists, ipratropium bromide, systemic corticosteroids, and magnesium sulfate. With regards to long-term management of asthma, stepwise escalation strategies following regular symptom assessment and lung function tests include using medications such as inhaled long-acting beta-agonists, inhaled and systemic corticosteroids, and leukotriene-receptor antagonists (21).

\section{Food Allergy}

In the last three decades, there has been a worldwide increase in the prevalence of food allergy with $3.5-8 \%$ of children having food allergies $(17,22,23)$. Food allergy is defined as an adverse immunological reaction that occurs on exposure to a food that re-occurs on repeat exposure (22). It is usually classified into immunoglobulin-E (IgE)-mediated food allergy, non-IgEmediated food allergy, or mixed IgE- and non-IgE-mediated allergy. IgE-mediated allergy has an acute onset (within $2 \mathrm{~h}$ of exposure), and presenting symptoms are often respiratory, skin, and gastrointestinal in nature, whereas non-IgE-mediated food allergy has a delayed onset of symptoms (from 1 to $24 \mathrm{~h}$ ), and the symptoms tend to be skin and/or gastrointestinal (24). The key investigations for diagnosing food allergy include taking a thorough clinical history, skin prick testing, serum-specific IgE, and the double-blinded oral food challenge, which considered the gold standard investigation (25). For food allergies proven by positive oral food challenges, recommendation is for strict avoidance of the causative allergen. For those patients who experience life-threatening symptoms of IgE-mediated food allergy, an emergency self-injectable adrenaline device is often prescribed as well. However, over the last 10 years, increasing research has been performed looking at the use of oral, sublingual, and epicutaneous immunotherapies to desensitize patients through tolerance induction (26).

\section{Understanding the Relationship between Food Allergy and Asthma}

Asthma and food allergy have been commonly shown to coexist with each other, especially as they often share risk factors (family history of allergy, atopic eczema, and asthma) but the way in which they interact and influence each other is yet to be fully understood. Studies have shown that food allergies can develop in the first year of life and precede the development of asthma $(17,27)$. There has also been increasing recognition that there is an allergic component to asthma as a disease with particular focus on the role of environmental allergens (i.e., house dust mite and cat allergens). Exacerbations of asthma can be caused by exposure to inhalant allergens, although avoidance of these allergens on asthma disease is not entirely understood. For example, a study that looked at the effectiveness of avoiding house dust mite allergen on asthma management found that using allergen-impermeable covers to avoid house dust mite allergen did not have a significant effect on clinical asthma (28). Schroeder et al. showed that there was a higher prevalence of asthma in children with food allergy as well as it occurring at a 7 earlier age compared to children without food allergy (29). Another study showed that compared to children who were not sensitized to common food and aeroallergens, those who were cosensitized had a higher risk of developing respiratory allergic disease (27). Studies have also looked at the timing of when food sensitization occurs and have shown that food sensitization early in life (within the first 2 years of life) is a strong predictor of allergy by school age and also children with food allergy have approximately double the chance of developing asthma and rhinitis $(30,31)$.

There also seems to be an association between asthma and non-IgE-mediated food allergy, although it is less prevalent than that seen in IgE-mediated allergy (32). In a study, approximately one-third of children with non-IgE-mediated food allergy had asthma and allergic rhinitis (33). Higher rates of asthma (26-66\%) have also been reported in eosinophilic esophagitis, which is considered a food allergy disease (34-36).

\section{ASTHMA TRIGGERED BY FOOD ALLERGENS}

The way in which food allergens may trigger asthma symptoms is not fully understood. The respiratory symptoms that occur in food allergic reactions commonly include rhinitis, bronchospasm, cough, and laryngeal edema (17). One theory is that particles of ingested food are inhaled into the airway, and exposure of these allergenic proteins to mast cells in the lungs causes inflammation and therefore respiratory symptoms $(17,24)$. Commonly documented respiratory reactions from aerosolized food proteins have been well documented over the years, mostly in adults. One of the most commonly described examples is baker's asthma where exposure to inhaled flour proteins causes an IgE-mediated type reaction, which manifests as asthmatic symptoms. Diagnosis is based on a history of work-related asthma symptoms, skin prick tests, and inhalation challenges to bakery allergens, which is the gold standard test (37). Aerosolized fish protein allergens have also been detected in open-air fish markets and can cause respiratory related symptoms due to inhalation of fish proteins (38). Similarly, occupational asthma and allergy has been reported in snow crab-processing workers who on cumulative exposure to snow crab have developed symptoms of asthma and allergy 
(39). With regards to children, Roberts et al. performed bronchial challenges in children with proven IgE-mediated food allergy and asthma using aerosolized foods (40). In this study, despite dietary avoidance of allergens (i.e., fish, milk, eggs, chickpeas, and buckwheat), the children had worse chronic asthma symptoms when there was environmental exposure to the foods (i.e., families cooked with the allergenic foods at home). However, when the families stopped cooking the allergenic food(s) at home, the child's symptoms improved, and they needed less inhaled corticosteroid treatment (40).

There has also been research performed on specific food allergens and their association with respiratory symptoms and the development of asthma. For example, in a large birth cohort study, having egg allergy during infancy was predictive of respiratory allergy later in childhood (2). In fact, they reported a positive predictive value of $80 \%$ if the child also had eczema (2). Rhodes et al. found that in a study of 100 infants who were deemed at high risk of developing asthma and atopy (i.e., had atopic parents), those who were sensitive to egg and milk in the first year of life was predictive of having asthma as an adult (5). Another study looking at peanut or tree nut allergies showed that patients with a severe history of asthma were at greater risk of life-threatening bronchospasm occurring after ingestion of nuts $(p<0.0001)(41)$.

\section{Factors Contributing to the Development of Food Allergy and Asthma}

In children, $4-8 \%$ of asthmatic patients have food allergies and approximately $50 \%$ of those with food allergies have allergic reactions that involve acute respiratory symptoms $(24,42)$. Various factors have been found to affect the risk of developing asthma in children with food allergy but some of the key factors include seasonal changes, the host immune response, and the use of anti-IgE treatments. Asthma exacerbations seem to coincide with seasonal changes, for example, increase aeroallergen levels such as grass pollen in the spring (43) and dust mite in the autumn (44). The specific-IgE antigens bind to mast cells and basophils causing an inflammatory response within the airways, which over time can cause airway modeling (45). The host immune response to allergens activates an inflammatory process causing allergic cytokines to be released and a subsequent rise in $\operatorname{IgE}$ levels, which have been shown to be associated with an increased risk of asthma $(45,46)$. In one study, they found that high $\operatorname{IgE}$ levels at 6 months old was associated with early-onset of asthma and also a strong relationship with the development of asthma in school-age years $(47,48)$. Milgrom et al. showed that $90 \%$ of children in their study with asthma had positive skin prick tests to common allergens (45). Also, the use of anti-IgE treatment (i.e., monoclonal anti-IgE antibodies such as omalizumab) in asthmatic patients has been successful, which suggests there is a role of $\operatorname{IgE}$ in the pathogenesis of asthma. There have been studies that have shown that omalizumab is effective in reducing the need for corticosteroids including complete withdrawal of corticosteroids compared to placebo, a reduction in asthmarelated symptoms, and improvement in quality of life of these patients $(45,49)$.

\section{Morbidity and Mortality in Asthma}

In adults, there is evidence that being allergic to more than one food is associated with an increase frequency of oral steroid use and a higher risk of lifetime hospitalizations and emergency department attendances (50). In children, a study showed that having a milk or peanut allergy was associated with an increased number of hospitalizations ( $p=0.009,0.016)$ (51). More specifically, having a milk allergy was associated with an increased use of systemic steroids ( $p=0.001)$ (51). Simpson et al. also showed that children with asthma who also had peanut allergy had a 1.59 times greater rate of systemic steroid use and 2.32 times greater rate of hospitalization (52).

There is also evidence that suggests that exposure to food allergens can be a risk factor for life-threatening asthma. For example, in a study of children with peanut allergy, 9\% (4/46) of the children died from an exacerbation of asthma that represents a significantly higher fatality rate for an asthmatic population (53). Roberts et al. compared children aged 1-16 years with life-threatening asthma (defined as requiring admission to pediatric intensive care) to those without nonlife-threatening asthma and showed that life-threatening asthma was significantly associated with having food allergy (OR 5.89, 1.06-32.61) and having multiple previous admissions for asthma (OR 9.85, 1.04-93.27) (54). Ernst et al. conducted a study in patients aged 5-54 years and 129 of the patients had "fatal" asthma. The main finding in this study was that over 10 prescriptions or more of bronchodilators was associated with an increased risk of near-fatal asthma, but they also found that food allergy was an independent risk factor for near-fatal asthma (odds ratio 5.1, 95\% CI 2.4-11.1) (55). Similarly, a case-control study showed that patients with near-fatal asthma (defined as requiring ventilation on intensive care unit) were more likely to be food allergic (OR 3.6, 1.6-8.2) and/or have had anaphylaxis (OR 5.6, 2.7-10.6) (56). Vogel et al. compared children who had ward-based care or ambulatory care (i.e., no hospitalization required) with children with potentially fatal asthma (requiring pediatric intensive care admission) and also found food allergy to be a risk factor for life-threatening asthma (57).

Asthma has also been identified as a risk factor for anaphylaxis and is associated with poorer outcomes in children with food allergy (24). Boyano-Martínez et al. conducted a study where children with cow's milk allergy had a 10 times higher chance of a severe reaction if they also had asthma (58). Another study found that the majority of fatal reactions attributed to food allergy were asthmatic reactions that occurred in patients on daily asthma treatment (59). Furthermore, in a series looking at fatalities due to food-induced anaphylactic reactions, the majority of the children were asthmatic, and their respiratory symptoms were identified as the main cause for the severity of their reactions (60). With this evidence over time, guidelines have been produced by various organizations of which pediatric allergists are recommended to prescribe self-injectable adrenaline devices to patients who have both food allergy and asthma $(24,61,62)$.

There have also been studies looking at preventative measures [i.e., house dust mite avoidance measures (i.e., protective mattress covers), allergen food avoidance] to prevent atopy in 
children, of which there is some evidence showing a reduction in respiratory symptoms (i.e., nocturnal cough, severe wheeze) by 1-2 years of age (63-65). Some studies suggest that immunotherapy to respiratory allergens can prevent allergic sensitization to new allergens, but this has not been observed in all studies $(66,67)$.

\section{Clinical Implications for Patients}

When reviewing food allergic or asthmatic children, a detailed clinical history should be taken to identify potential triggers for both allergic disease and asthma. If a specific trigger can be identified, primary advice is for avoidance of the allergen. Asthmatic patients with food allergies require regular assessments, careful monitoring and dietary and emergency management plans, review of treatment, and medication adherence reviews. In cases of status asthmaticus, the use of intramuscular adrenaline should be considered if there is a history of food allergies. Equally, patients who have known food allergies with respiratory symptoms should be offered beta-agonist inhalers.

\section{CONCLUSION}

Children who have both food allergies and asthma are at an increased risk of severe asthmatic episodes and may be at greater

\section{REFERENCES}

1. Shaker M. New insights into the allergic march. Curr Opin Pediatr (2014) 26(4):516-20. doi:10.1097/MOP.0000000000000120

2. Tariq SM, Matthews SM, Hakim EA, Arshad SH. Egg allergy in infancy predicts respiratory allergic disease by 4 years of age. Pediatr Allergy Immunol (2000) 11(3):162-7. doi:10.1034/j.1399-3038.2000.00077.x

3. Hill DJ, Hosking CS. Food allergy and atopic dermatitis in infancy: an epidemiologic study. Pediatr Allergy Immunol (2004) 15(5):421-7. doi:10.1111/j.1399-3038.2004.00178.x

4. Illi S, von Mutius E, Lau S, Nickel R, Grüber C, Niggemann B, et al. The natural course of atopic dermatitis from birth to age 7 years and the association with asthma. J Allergy Clin Immunol (2004) 113(5):925-31. doi:10.1016/ j.jaci.2004.01.778

5. Rhodes HL, Sporik R, Thomas P, Holgate ST, Cogswell JJ. Early life risk factors for adult asthma: a birth cohort study of subjects at risk. J Allergy Clin Immunol (2001) 108(5):720-5. doi:10.1067/mai.2001.119151

6. Allen KJ, Koplin JJ. Why does Australia appear to have the highest rates of food allergy? Pediatr Clin North Am (2015) 62(6):1441-51. doi:10.1016/ j.pcl.2015.07.005

7. Kelleher MM, Dunn-Galvin A, Gray C, Murray DM, Kiely M, Kenny L, et al. Skin barrier impairment at birth predicts food allergy at 2 years of age. J Allergy Clin Immunol (2016) 137(4):1111-6.e1-8. doi:10.1016/j.jaci.2015. 12.1312

8. Du Toit G, Roberts G, Sayre PH, Bahnson HT, Radulovic S, Santos AF, et al. Randomized trial of peanut consumption in infants at risk for peanut allergy. N Engl J Med (2015) 372(9):803-13. doi:10.1056/NEJMoa1414850

9. Wei-LiangTanJ,Valerio C,BarnesEH,TurnerPJ, Van Asperen PA,KakakiosAM, et al. A randomized trial of egg introduction from 4 months of age in infants at risk for egg allergy. J Allergy Clin Immunol (2017) 139(5):1621-8.e8. doi:10.1016/j.jaci.2016.08.035

10. Perkin MR, Logan K, Tseng A, Raji B, Ayis S, Peacock J, et al. Randomized trial of introduction of allergenic foods in breast-fed infants. N Engl J Med (2016) 374(18):1733-43. doi:10.1056/NEJMoa1514210

11. McAleer MA, Irvine AD. The multifunctional role of filaggrin in allergic skin disease. J Allergy Clin Immunol (2013) 131(2):280-91. doi:10.1016/ j.jaci.2012.12.668 risk of food-induced anaphylaxis and also food allergen-triggered asthmatic episodes. It is important that clinicians educate patients appropriately regarding the higher risk of life-threatening asthma and anaphylaxis and ensure they receive regular assessments regarding their treatment and management.

\section{Summary of key points}

- Food allergic infants are at increased risk of developing asthma.

- Children with both asthma and food allergies are at increased risk of severe asthmatic episodes.

- Children with both asthma and food allergies may be at greater risk of allergen-triggered asthma episodes and food-induced anaphylaxis.

- Patients with known IgE-mediated food allergies and asthma should have immediate access to self-injectable adrenaline and inhaled beta-agonists.

\section{AUTHOR CONTRIBUTIONS}

All the authors (RXF, GdT, and AF) were involved in the writing and editing of the manuscript.

\section{FUNDING}

There was no funding associated with this publication.

12. Horimukai K, Morita K, Narita M, Kondo M, Kitazawa H, Nozaki M, et al. Application of moisturizer to neonates prevents development of atopic dermatitis. J Allergy Clin Immunol (2014) 134(4):824-30.e6. doi:10.1016/ j.jaci.2014.07.060

13. Martin PE, Eckert JK, Koplin JJ, Lowe AJ, Gurrin LC, Dharmage SC, et al. Which infants with eczema are at risk of food allergy? Results from a population-based cohort. Clin Exp Allergy (2015) 45(1):255-64. doi:10.1111/ cea.12406

14. Fox AT, Sasieni P, du Toit G, Syed H, Lack G. Household peanut consumption as a risk factor for the development of peanut allergy. J Allergy Clin Immunol (2009) 123(2):417-23. doi:10.1016/j.jaci.2008.12.014

15. Chan SM, Turcanu V, Stephens AC, Fox AT, Grieve AP, Lack G. Cutaneous lymphocyte antigen and alpha4beta7 T-lymphocyte responses are associated with peanut allergy and tolerance in children. Allergy (2012) 67(3):336-42. doi:10.1111/j.1398-9995.2011.02765.x

16. Brown SJ, Asai Y, Cordell HJ, Campbell LE, Zhao Y, Liao H, et al. Lossof-function variants in the filaggrin gene are a significant risk factor for peanut allergy. J Allergy Clin Immunol (2011) 127(3):661-7. doi:10.1016/ j.jaci.2011.01.031

17. Caffarelli C, Garrubba M, Greco C, Mastrorilli C, Povesi Dascola C. Asthma and food allergy in children: is there a connection or interaction? Front Pediatr (2016) 4:34. doi:10.3389/fped.2016.00034

18. World Health Organization. Asthma: Definition. Chronic Respiratory Diseases. (2016). Available from: http://www.who.int/respiratory/asthma/ definition/en

19. Foroughi S, Thyagarajan A, Stone KD. Advances in pediatric asthma and atopic dermatitis. Curr Opin Pediatr (2005) 17(5):658-63. doi:10.1097/01. mop.0000178386.61932.0b

20. Pardue Jones B, Fleming GM, Otillio JK, Asokan I, Arnold DH. Pediatric acute asthma exacerbations: evaluation and management from emergency department to intensive care unit. J Asthma (2016) 53(6):607-17. doi:10.3109/ 02770903.2015.1067323

21. British Thoracic Society, S.I.G.N. Quick Reference Guide: British Guideline on the Management of Asthma. Edinburgh: Healthcare Improvement Scotland (2016).

22. Sampson HA. Update on food allergy. JAllergy Clin Immunol (2004) 113(5):805-19; quiz 820. doi:10.1016/j.jaci.2004.03.014 
23. Anagnostou K, Meyer R, Fox A, Shah N. The rapidly changing world of food allergy in children. F1000Prime Rep (2015) 7:35. doi:10.12703/P7-35

24. Roberts G, Lack G. Food allergy and asthma - what is the link? Paediatr Respir $\operatorname{Rev}(2003)$ 4(3):205-12. doi:10.1016/S1526-0542(03)00058-7

25. Muraro A, Dubois AE, Dunn-Galvin A, Hourihane JO, de Jong NW, Meyer R, et al. EAACI food allergy and anaphylaxis guidelines. Food allergy healthrelated quality of life measures. Allergy (2014) 69(7):845-53. doi:10.1111/ all.12405

26. Pesek RD, Jones SM. Current and emerging therapies for IgE-mediated food allergy. Curr Allergy Asthma Rep (2016) 16(4):28. doi:10.1007/ s11882-016-0610-0

27. Alduraywish SA, Standl M, Lodge CJ, Abramson MJ, Allen KJ, Erbas B. Is there a march from early food sensitization to later childhood allergic airway disease? Results from two prospective birth cohort studies. Pediatr Allergy Immunol (2016) 28(1):30-7. doi:10.1111/pai.12651

28. Woodcock A, Forster L, Matthews E, Martin J, Letley L, Vickers M, et al. Control of exposure to mite allergen and allergen-impermeable bed covers for adults with asthma. N Engl J Med (2003) 349(3):225-36. doi:10.1056/ NEJMoa023175

29. Schroeder A, Kumar R, Pongracic JA, Sullivan CL, Caruso DM, Costello $\mathrm{J}$, et al. Food allergy is associated with an increased risk of asthma. Clin Exp Allergy (2009) 39(2):261-70. doi:10.1111/j.1365-2222.2008. 03160.x

30. Illi S, von Mutius E, Lau S, Nickel R, Niggemann B, Sommerfeld C, et al. The pattern of atopic sensitization is associated with the development of asthma in childhood. J Allergy Clin Immunol (2001) 108(5):709-14. doi:10.1067/mai. 2001.118786

31. Hill DA, Grundmeier RW, Ram G, Spergel JM. The epidemiologic characteristics of healthcare provider-diagnosed eczema, asthma, allergic rhinitis, and food allergy in children: a retrospective cohort study. BMC Pediatr (2016) 16:133. doi:10.1186/s12887-016-0673-z

32. Latcham F, Merino F, Lang A, Garvey J, Thomson MA, Walker-Smith JA, et al. A consistent pattern of minor immunodeficiency and subtle enteropathy in children with multiple food allergy. J Pediatr (2003) 143(1):39-47. doi:10.1016/S0022-3476(03)00193-8

33. Meyer R, Fleming C, Dominguez-Ortega G, Lindley K, Michaelis L, Thapar $\mathrm{N}$, et al. Manifestations of food protein induced gastrointestinal allergies presenting to a single tertiary paediatric gastroenterology unit. World Allergy Organ J (2013) 6(1):13. doi:10.1186/1939-4551-6-13

34. Roy-Ghanta S, Larosa DF, Katzka DA. Atopic characteristics of adult patients with eosinophilic esophagitis. Clin Gastroenterol Hepatol (2008) 6(5):531-5. doi:10.1016/j.cgh.2007.12.045

35. Sugnanam KK, Collins JT, Smith PK, Connor F, Lewindon P, Cleghorn G, et al. Dichotomy of food and inhalant allergen sensitization in eosinophilic esophagitis. Allergy (2007) 62(11):1257-60. doi:10.1111/j.1398-9995.2007. 01454.x

36. Assảad AH, Putnam PE, Collins MH, Akers RM, Jameson SC, Kirby CL, et al. Pediatric patients with eosinophilic esophagitis: an 8-year follow-up. J Allergy Clin Immunol (2007) 119(3):731-8. doi:10.1016/j.jaci.2006.10.044

37. Quirce S, Diaz-Perales A. Diagnosis and management of grain-induced asthma. Allergy Asthma Immunol Res (2013) 5(6):348-56. doi:10.4168/ aair.2013.5.6.348

38. Taylor AV, Swanson MC, Jones RT, Vives R, Rodriguez J, Yunginger JW, et al. Detection and quantitation of raw fish aeroallergens from an open-air fish market. J Allergy Clin Immunol (2000) 105(1 Pt 1):166-9. doi:10.1016/ S0091-6749(00)90192-1

39. Gautrin D, Cartier A, Howse D, Horth-Susin L, Jong M, Swanson M, et al. Occupational asthma and allergy in snow crab processing in Newfoundland and Labrador. Occup Environ Med (2010) 67(1):17-23. doi:10.1136/ oem.2008.039578

40. Roberts G, Golder N, Lack G. Bronchial challenges with aerosolized food in asthmatic, food-allergic children. Allergy (2002) 57(8):713-7. doi:10.1034/j.1398-9995.2002.03366.x

41. Summers CW, Pumphrey RS, Woods CN, McDowell G, Pemberton PW, Arkwright PD. Factors predicting anaphylaxis to peanuts and tree nuts in patients referred to a specialist center. J Allergy Clin Immunol (2008) 121(3):632-38.e2. doi:10.1016/j.jaci.2007.12.003
42. James JM. Respiratory manifestations of food allergy. Pediatrics (2003) 111 (6 Pt 3):1625-30.

43. Alduraywish SA, Lodge CJ, Vicendese D, Lowe AJ, Erbas B, Matheson MC, et al. Sensitization to milk, egg and peanut from birth to 18 years: a longitudinal study of a cohort at risk of allergic disease. Pediatr Allergy Immunol (2015) 27(1):83-91. doi:10.1111/pai.12480

44. van der Heide S, De Monchy JG, De Vries K, Dubois AE, Kauffman HF. Seasonal differences in airway hyperresponsiveness in asthmatic patients: relationship with allergen exposure and sensitization to house dust mites. Clin Exp Allergy (1997) 27(6):627-33. doi:10.1111/j.1365-2222.1997. tb01189.x

45. Milgrom H, Berger W, Nayak A, Gupta N, Pollard S, McAlary M, et al. Treatment of childhood asthma with anti-immunoglobulin E antibody (omalizumab). Pediatrics (2001) 108(2):E36. doi:10.1542/peds.108.2.e36

46. Burrows B, Martinez FD, Halonen M, Barbee RA, Cline MG. Association of asthma with serum IgE levels and skin-test reactivity to allergens. N Engl J Med (1989) 320(5):271-7. doi:10.1056/NEJM198902023200502

47. Mrazek DA, Klinnert M, Mrazek PJ, Brower A, McCormick D, Rubin B, et al. Prediction of early-onset asthma in genetically at-risk children. Pediatr Pulmonol(1999)27(2):85-94.doi:10.1002/(SICI)1099-0496(199902)27:2<85:: AID-PPUL4>3.0.CO;2-B

48. Klinnert MD, Nelson HS, Price MR, Adinoff AD, Leung DY, Mrazek DA. Onset and persistence of childhood asthma: predictors from infancy. Pediatrics (2001) 108(4):E69. doi:10.1542/peds.108.4.e69

49. D’Amato G, Liccardi G, Noschese P, Salzillo A, D'Amato M, Cazzola M. AntiIgE monoclonal antibody (omalizumab) in the treatment of atopic asthma and allergic respiratory diseases. Curr Drug Targets Inflamm Allergy (2004) 3(3):227-9. doi:10.2174/1568010043343615

50. Berns SH, Halm EA, Sampson HA, Sicherer SH, Busse PJ, Wisnivesky JP. Food allergy as a risk factor for asthma morbidity in adults. J Asthma (2007) 44(5):377-81. doi:10.1080/02770900701364031

51. Simpson AB, Glutting J, Yousef E. Food allergy and asthma morbidity in children. Pediatr Pulmonol (2007) 42(6):489-95. doi:10.1002/ppul.20605

52. Simpson $A B$, Yousef E, Hossain J. Association between peanut allergy and asthma morbidity. J Pediatr (2010) 156(5):777-81, 781.e1. doi:10.1016/j.jpeds. 2009.11.080

53. Bock SA, Atkins FM. The natural history of peanut allergy. J Allergy Clin Immunol (1989) 83(5):900-4. doi:10.1016/0091-6749(89)90103-6

54. Roberts G, Patel N, Levi-Schaffer F, Habibi P, Lack G. Food allergy as a risk factor for life-threatening asthma in childhood: a case-controlled study. J Allergy Clin Immunol (2003) 112(1):168-74. doi:10.1067/mai.2003.1569

55. Ernst P, Habbick B, Suissa S, Hemmelgarn B, Cockcroft D, Buist AS, et al. Is the association between inhaled beta-agonist use and life-threatening asthma because of confounding by severity? Am Rev Respir Dis (1993) 148(1):75-9. doi:10.1164/ajrccm/148.1.75

56. Mitchell I, Tough SC, Semple LK, Green FH, Hessel PA. Near-fatal asthma: a population-based study of risk factors. Chest (2002) 121(5):1407-13. doi:10.1378/chest.121.5.1407

57. Vogel NM, Katz HT, Lopez R, Lang DM. Food allergy is associated with potentially fatal childhood asthma. JAsthma (2008) 45(10):862-6. doi:10.1080/02770900802444195

58. Boyano-Martínez T, García-Ara C, Pedrosa M, Díaz-Pena JM, Quirce S. Accidental allergic reactions in children allergic to cow's milk proteins. J Allergy Clin Immunol (2009) 123(4):883-8. doi:10.1016/j.jaci.2008.12.1125

59. Pumphrey R. Anaphylaxis: can we tell who is at risk of a fatal reaction? Curr Opin Allergy Clin Immunol (2004) 4(4):285-90. doi:10.1097/01.all. 0000136762.89313.0b

60. Bock SA, Munoz-Furlong A, Sampson HA. Fatalities due to anaphylactic reactions to foods. J Allergy Clin Immunol (2001) 107(1):191-3. doi:10.1067/ mai.2001.112031

61. Sicherer SH, Sampson HA. Food allergy: epidemiology, pathogenesis, diagnosis, and treatment. J Allergy Clin Immunol (2014) 133(2):291-307; quiz 308. doi:10.1016/j.jaci.2013.11.020

62. Muraro A, Roberts G, Worm M, Bilò MB, Brockow K, Fernández Rivas M, et al. Anaphylaxis: guidelines from the European Academy of Allergy and Clinical Immunology. Allergy (2014) 69(8):1026-45. doi:10.1111/ all.12437 
63. Custovic A, Simpson BM, Simpson A, Kissen P, Woodcock A; NAC Manchester Asthma and Allergy Study Group. Effect of environmental manipulation in pregnancy and early life on respiratory symptoms and atopy during first year of life: a randomised trial. Lancet (2001) 358(9277):188-93. doi:10.1016/ S0140-6736(01)05406-X

64. Koopman LP, van Strien RT, Kerkhof M, Wijga A, Smit HA, de Jongste JC, et al. Placebo-controlled trial of house dust mite-impermeable mattress covers: effect on symptoms in early childhood. Am J Respir Crit Care Med (2002) 166(3):307-13. doi:10.1164/rccm.2106026

65. Arshad SH. Primary prevention of asthma and allergy. J Allergy Clin Immunol (2005) 116(1):3-14; quiz 15. doi:10.1016/j.jaci.2005.03.043

66. Jacobsen L, Niggemann B, Dreborg S, Ferdousi HA, Halken S, Høst A, et al. Specific immunotherapy has long-term preventive effect of seasonal and perennial asthma: 10-year follow-up on the PAT study. Allergy (2007) 62(8):943-8. doi:10.1111/j.1398-9995.2007.01451.x
67. Zolkipli Z, Roberts G, Cornelius V, Clayton B, Pearson S, Michaelis L, et al. Randomized controlled trial of primary prevention of atopy using house dust mite allergen oral immunotherapy in early childhood. J Allergy Clin Immunol (2015) 136(6):1541-7.e1-11. doi:10.1016/j.jaci.2015.04.045

Conflict of Interest Statement: The authors declare no conflicts of interest regarding the writing of this mini-review.

Copyright (c) 2017 Foong, du Toit and Fox. This is an open-access article distributed under the terms of the Creative Commons Attribution License (CC BY). The use, distribution or reproduction in other forums is permitted, provided the original author(s) or licensor are credited and that the original publication in this journal is cited, in accordance with accepted academic practice. No use, distribution or reproduction is permitted which does not comply with these terms. 